Piotr Prósinowski

Piotr Krzywdziński

Uniwersytet Gdański

\title{
Potencjał gier wideo: o nadawaniu znaczeń, dyskusji, inkulturacji i rozwoju literackim młodych graczy
}

\author{
Wstęp \\ Fikcja a codzienność - pedagogiczna podstawa badania \\ gier i innych tekstów kultury
}

Gry wideo - tak jak literatura czy film - są rodzajem tekstów kultury (Szeja 2004) i tak samo jak literatura (Nikolajeva 2014) wraz z innymi inkarnacjami kultury towarzyszą dzieciom od najmłodszych lat. To w ich kontekście wzrastają, uczą się, rozwijają, poznają świat. To w tych inkarnacjach dopatrujemy się mocy inkulturacji i socjalizacji.

Fikcja - także w formie gier, filmów, literatury - jest znacząca. Fikcja wychowuje (Miller 1977; Rodziewicz 2011). Na wiele sposobów pomaga w poznaniu rzeczywistości. Po pierwsze fikcja stawia przed dzieckiem pewne sądy, przekonania na temat świata. Po drugie namawia do analizy świata, do niełatwej próby jego zrozumienia. Po trzecie po poznaniu świat fikcyjny jest konstruktem, wobec którego odbiorca może dokonać porównania rzeczywistości, w której żyje; czytelnicy, poznając uniwersum książki czy gry, odnoszą je do znanej rzeczywistości, porównują. Na przykładach fikcyjnych, zaczerpniętych między innymi z popkultury, można nauczać i ukazywać, że edukacja nie musi być oderwana od istotnych dla młodych ludzi (i nie tylko) zjawisk, produktów, tekstów kultury (Wierzba 2015).

Gry jako twory ludyczne ściśle powiązane są z zabawą, a cytując Johana Huizingę „Każda zabawa coś oznacza” (Huizinga 1985), mimo że rozumiana jest jako antyteza powagi (Huizinga 1985: 17). Twór ludyczny jest konstruktem, z którym można pracować, który może inspirować, może stawiać przed odbiorcą problemy i tezy, dzięki swojej zdolności do angażowania może nakłaniać do dalszych aktywności. W grach wideo angażowanie ma specjalne znaczenie, bo jest nierzadko efektem immersyjności (Filiciak 2006) tegoż medium. Zezwala ona na 
wyjątkowe doświadczanie fikcyjnego uniwersum, na zdobywanie doświadczenia z „bezpiecznej odległości”.

Gra wideo jest także ludyczną okazją do działania i eksperymentowania. Ponownie - gra coś oznacza. Dzięki swojej formie metaforycznie odnosi się do tego, co codzienne i znane; zezwala na swojego rodzaju dialog gracza ze stawianymi tezami i popkulturowymi alegoriami. Dialog ten nie jest jałowy, raczej umożliwia poznawanie istotnych fenomenów, interakcję oraz, przy odpowiednich warunkach, rozwój umiejętności analizy tego, co przedstawione, usposabia do treningu nadawania i odczytywania znaczeń.

Gra wideo jest tekstem kultury uformowanym mocą inkulturacji. Dotyka kwestii wszechobecnych i istotnych, jak chociażby płeć i role płciowe (Prósinowski, Ranachowska 2014; Prósinowski 2015), ergo uczestniczy w formowaniu rozumienia świata (w tym przypadku świata społecznego) lub przynajmniej prezentuje pewne konstrukty, oferuje wyzwanie poznawcze. Gry są także polisensoryczne. Angażują wzrok poprzez obraz, wizualną kreację uniwersum. Atmosferę kształtują dzięki dźwiękom (ugłosowieniu postaci, muzyce, dźwiękom otoczenia). Wymagają chociażby dotyku i ruchu (poprzez myszkę, klawiaturę, pad, kontrolery ruchu) do np. kierowania postacią. Nie można także zapomnieć o rozwijającej się technologi VR (ang. virtual reality), dzięki której doznawanie staje się jeszcze mocniej podkreślone. Czy mogą pobudzać do czegoś jeszcze? Do zachowań kreatywnych? Do kreatywnego pisania? ${ }^{1}$

Próbując odpowiedzieć na te oraz na inne pytania, poruszając kwestie istotne dla edukacji, wychowania czy rozwoju człowieka w ogóle, sięgnę do konkretnego przykładu gry wideo - Elegy for a Dead World - stworzonej przez Dejobaan Games, jak i innych produkcji pozostałych deweloperów gier.

\section{Gra Elegy for a Dead World jako przykład ludycznej okazji edukacyjnej}

Gry wideo są kompleksowymi konstruktami posiadającymi swoje cechy, możliwości oraz ograniczenia. W celu ukazania możliwych potencjałów gier w ogóle posłużę się głównie konkretną grą wideo - Elegy for a Dead World - inne produkcje utrzymując $w$ formie dygresji czy dodatkowych przykładów, bowiem zależy mi na ukazaniu, że gry generalnie, ze względu na swoją popularność, ludyczność czy atrakcyjność, zasługują na atencje ze strony pedagogów, nauczycieli i psychologów. Jednocześnie warto nadmienić, że istnieją także inne, wartościowe, interesujące oraz potencjalnie pomocne gry (zarówno jako narzędzia edukacyjne, jak

${ }^{1}$ Przez kreatywne pisanie rozumiem nieprzymusowe, angażujące zajęcia pisarskie, wykonywane $\mathrm{z}$ chęcią, będące znaczące dla autora (gracza), budzące zadowolenie, będące przejawem twórczości, mogące być przyczynkiem do szeroko rozumianego rozwoju osoby piszącej. 
i materiały dyskusyjne), które można wykorzystać w edukacji, a które mogą być pomocne dla wielu uczniów w całej rozpiętości wiekowej; Elegy służy tu natomiast jako bardzo dobry przykład edukacyjności gier.

\section{Charakterystyka produktu}

Elegry for a Dead World to gra wideo wydana przez amerykańskie studio niezależne Dejobaan Games. Gra zaklasyfikowana została do gatunku eksploracyjnych, artystycznych oraz indie (skrót od ang. independent - niezależna). Nie ma ona szczególnych ograniczeń wiekowych; oznaczeń ostrzegających o wulgarnym języku, strachu czy występowaniu innych treści mogących budzić wątpliwości u niektórych odbiorców. Oto jak twórcy opisują swój produkt:

W Elegy for a Dead World masz okazję odwiedzić odległe planety i tworzyć opowieści o ludziach, którzy niegdyś je zamieszkiwali. Otworzyły się trzy portale do nieznanych światów. Ziemia wysłała grupę odkrywców, by zbadali nieznane miejsca, jednakże z powodu pewnych wydarzeń pozostał tylko jeden odkrywca. Twoja misja nie uległa zmianie: odkryj nieznane światy, opisz je w jedynych dokumentach, jakie kiedykolwiek trafią w ręce innych ludzi. [...] Elegia powstała, by każdy mógł pisać. Podczas eksploracji gra będzie pomagać wam w tworzeniu narracji. [...] Każdy ze światów oferuje wiele zestawów podpowiedzi; każdy z zestawów stworzony został do tego, by zainspirować zupełnie inne historie. Elegia może poprosić cię o napisanie krótkiej historii o ostatnich dniach mieszkańców, piosenki o rezygnacji, poezji o tematyce wojny. Na bardziej zaawansowanych poziomach możecie otrzymać nowe informacje już w trakcie rozgrywki. Informacje rzucające nowe światło na wydarzenia oraz nakłaniające do spojrzenia na swoją opowieść pod zupełnie innym kątem. Lubimy patrzeć na naszą grę jak na wyzwanie - napisanie własnej historii pomimo „ograniczonego miejsca na kartce" (Dejobaan Games 2014).

Jak widać, gra została stworzona intencjonalnie z myślą o pobudzaniu kreatywności; stara się inspirować różnego rodzaju historie, nie naprowadzać na jedną właściwą interpretacje audiowizualnego uniwersum. Wspierają to także podpowiedzi (a raczej dostępne formy) pisarskie. Wybierając jeden ze światów, otrzymamy takie sugestie: The Four Ages of Byron's World (Cztery lata świata Byrona), Freeform Writing (Swobodny tekst), Darkness by Lord Byron (Ciemność Lorda Byrona), This Vacation is Terrible (Te wakacje są straszne), 10 Choices We Made (10 decyzji, które podjęliśmy), War of the Worlds (Wojna światów), Plundering Byron: A Musical (Plądrujący Byron: musical), This Was My World (To byt mój świat). Jak wynika z powyższego wyliczenia, propozycje są zróżnicowane (a każdą z nich można dodatkowo modyfikować - nawet jeśli wybierzemy opcję podpowiedzi w rodzaju „dokończ zdania” to, co znajduje się przed luką lub po niej, także można modyfikować), budują bogatą ofertę dla graczy-pisarzy na różnym poziomie umiejętności. Wyraźne są także nawiązania do pisarza - George’a Byrona. 
Gra zbudowana jest w sposób na tyle otwarty, że pozwala graczom na podejmowanie decyzji, pozostawia swobodę wyboru różnych form pisarskich. Udostępnienie przez autorów dużej ilości stylów/formatów nie jest bez znaczenia. Przypomina to rodzaj wspierania rozwoju językowego, celowe i niezwykle ważne stwarzanie pozytywnych warunków (mnogich propozycji i ofert) dla podejmowania przez jednostkę aktywności językowej (Stawinoga 2007: 53) esencjonalnej w rozwoju kreatywności. Wielu badaczy właśnie w pisaniu dopatruje się zarówno manifestacji kreatywności, jak i okazji to treningu tejże (Ming Cheung, Kam Tse, Wh Tsang 2003).

Bardzo istotną - zarówno teoretycznie jak i praktycznie - cechą Elegy for a Dead World jest prosta umiejętność dzielenia się swoimi historiami. Gra posiada opcję udostępniania powieści stworzonych z myślą o konkretnych światach, a każde udostępnienie będzie zilustrowane dzięki wygenerowanemu obrazkowi (jeśli przykładowo fragment tekstu powstał, gdy w tle, za bohaterem, stała góra, na ilustracji znajdować się będzie ten właśnie „wirtualny pejzaż”). Wśród opcji znajduje się możliwość eksportowania historii do plików, które także można wydrukować i rozprzestrzeniać w postaci fizycznej, co także ma zachęcać graczy do „wymieniania się" swoimi historiami.

Cyfrowe opowieści, poznawanie świata i inspiracje freinetowskie

Przyglądając się konstrukcji Elegy for a Dead World, doszliśmy do wniosku, że na swój sposób można dostrzec w niej inkarnację myśli freinetowskich. Mam tu na myśli metodę swobodnego tekstu, który cechują „spontaniczność, twórczość, związek z życiem, bliskie i stałe kontakty ze środowiskiem, głęboka ekspresja przeżyć dziecka" (Freinet 1976: 393). Właśnie pod kątem tychże cech ocenialibyśmy grę jako silnie związaną z pedagogiką Celestyna Freinet. Oto w jaki sposób manifestują się wspomniane cechy w analizowanej grze:

- spontaniczność - zabawa sama w sobie nierzadko jest wiązana ze spontanicznością (Paleczny 2012: 19). W przypadku gier wideo objawia się w inny sposób. To, co widzimy na ekranie lub słyszymy dzięki głośnikom, jest bodźcem. Często czymś nowym. Poleceniem lub „szturchnięciem” do reagowania, bo chcemy, by „nasza postać” rozwijała się; gracz pragnie poznać historię, na którą na bieżąco reaguje. Człowiek z grą wideo także bawi się spontanicznie, uruchamia ją „tu i teraz”, ponieważ ma chwilę wolnego czasu, skończył pracę, może się bawić; w trakcie rozgrywki jest medialnie zaskakiwany oraz zachęcany do reakcji. Bez reagowania, bez obecności gracza gra wideo straci sens, przestaje być istotna, bo to odbiór, dialog i reakcja nadają grze sens i znaczenie;

- związek z życiem- gry wideo mają związek z życiem. Chociażby - i tu powracamy do Huizingi (1985) - dzięki swojemu potencjałowi kulturotwórczemu. Można z pewnością stwierdzić, że działanie ekspresyjne jest ściśle 
związane z codziennością, nierzadko jest realizacją potrzeb wewnętrznych. Gry wideo w XXI wieku weszły do kultury codzienności, są obecne w życiu człowieka już od pierwszych lat życia, później natomiast „starzeją się i zmieniają" wraz z odbiorcami, takie wnioski można wynieść z badań GIT KIDS (Game Industry Trends 2014) oraz Jestem Graczem (Jestem Graczem 2015). Gry obrazują oczekiwania społeczne (np. wobec grup społecznych, kobiet, mężczyzn, organizacji) poprzez prezentowanie postaci/zjawisk oraz pobudzanie dyskusji wokół tychże. Jednocześnie, jako element popkultury, są wpisane w życie „tu i teraz”, jak twierdzi Paulina Wierzba (2015), są znaczące dla młodzieży (i nie tylko tej grupy) i edukacji, a ignorowanie popkultury oraz tego, co ze sobą niesie, nie jest niczym innym jak ignorowaniem młodzieży i dzieci wzrastających w jej duchu (za Wierzba: Melosik 2012: 18);

- bliskie i stałe kontakty ze środowiskiem - gry wideo często oskarżane są o zły wpływ na kontakty gracza $\mathrm{z}$ otoczeniem (Braun-Gałkowska, Ulfik-Jaworska 2002: 221-222); powszechnie uważa się, że gry „izolują od ludzi”. Kwestia jest jednak bardziej złożona. O ile spędzanie czasu na grach oraz zajęciach okołogrowych (udzielanie się na forach społecznościowych, tworzenie fanartów ${ }^{2}$ oraz fanfiction ${ }^{3}$ ) faktycznie musi odbywać się kosztem czasu niespędzanego przed komputerem (ergo czasami kosztem czasu spędzanego z rodziną, znajomymi), nie zawsze oznacza to izolację od ludzi. Często komunikacja zaczyna przybierać inny kształt. Przykładem mogą być fandomy, grupy ludzi tworzących fanart oraz fanfiction; grupy wymieniające się poglądami, spostrzeżeniami. Często zdarza się tak, że poprzez fanfiction oraz fanart dochodzi do przełomów życiowych (lub co najmniej zdarzeń znaczących) wśród fanów, jak przykładowo dzielenie się pierwszymi tworami artystycznymi, rozpoczynanie całożyciowych przyjaźni, poznawanie partnerów/partnerek życiowych, coming out ${ }^{4}$ poprzez zamieszczanie tworów cechujących homoerotyzm (Dennis 2010). Elegy for a Dead World cechuje możliwość komunikacji z innymi twórcami poprzez tekst. Dochodzi do przemieszania się pojęć twórca i odbiorca; dochodzi do sytuacji, w których tuż po opublikowaniu swojej wersji opowiadania o wybranym świecie gracze sprawdzają, jak bardzo ich wizja różni się od opowiadania

${ }^{2}$ Fanart - sztuka zainspirowana grami, serialami, filmami, książkami, zazwyczaj polegająca na rysowaniu miejsc, postaci i zdarzeń z tychże. Często jest to wyrażenie poparcia, uwielbienia, uznania wobec konkretnego dzieła. Ostatnim etapem tworzenia fanart jest zazwyczaj podzielenie się nim z innymi fanami poprzez umieszczenie dzieła do wglądu na portalu (np. deviantArt).

${ }^{3}$ Fanfiction - podobnie jak fanart jest to rodzaj oddania hołdu, pokazanie poparcia czy uznania konkretnemu tworowi kultury poprzez tworzenie tekstów (głównie opowiadań). Ostatnim etapem tworzenia fanfiction jest zazwyczaj podzielenie się tekstem $\mathrm{z}$ innymi fanami poprzez umieszczenie dzieła do wglądu na portalu (np. fanfiction.net).

${ }^{4}$ Coming out - wyjście (w domyśle z ukrycia, z tzw. „szafy”) - ujawnienie swej nienormatywnej (homoseksualnej, biseksualnej, panseksualnej) orientacji seksualnej. 
umieszczonego przez osobę mieszkającą po drugiej stronie kontynentu lub nawet planety. Także graczy, wbrew społecznym przekonaniom, cechują bliskie i stałe kontakty ze środowiskiem, czasami jednak „niewidzialne” dla opiekunów i rodziców istniejących tu i teraz; środowiskiem internetowym, bogatym w inne doznania i inne rodzaje/jakości relacji i znajomości. Warto podkreślić, że w trakcie tworzenia niektórzy odbiorcy gier nawiązują współpracę i zaczynają wspólnie pracować nad swoimi projektami - dochodzić może więc do dalszego rozwoju znajomości;

- twórczość oraz głęboka ekspresja przeżyć dziecka - cechy twórczości oraz głębokiej ekspresji postanowiliśmy omówić jako jeden podpunkt z powodu łączenia się tychże wartości. Pisanie jest twórcze (Ming Cheung, Kam Tse, Wh Tsang 2003). To możliwość wyrażenia siebie, swoich potrzeb, pragnień, myśli, obaw (oraz wielu innych stanów) przez fikcję, tworzenie. Jest treningiem kreatywności przygotowującym do codziennych wyzwań. Elegy jest skonstruowana do inspirowania, do wspomnianego „szturchania” i „chwytania”, aby to, co wewnątrz odbiorcy, mogło być poddane eksternalizacji, mogło stać się nie tylko dziełem autorskim, ale także materiałem możliwym do poznania przez innych (tu: graczy, odbiorców); materiałem, z którym można pracować, który dalej może inspirować już jako nowa jakość. Gra wideo ma się stać okazją do „odczuwania potrzeby wyrażenia piórem tego, co nas przepełnia” (Freinet 1976: 393). To właśnie gra wideo staje się kontekstem oraz zapewnia przestrzeń potrzebną do zaistnienia nowych tekstów; swobodnych ekspresji. Staje się to wydarzeniem wyjątkowym dla autora - twórczym doznaniem. Wrażenie to opisuje znany pisarz - Neil Gaiman:

Najlepszą rzeczą w pisaniu fikcji, jest ten moment, gdy opowieść zaczyna wrzeć i zaczyna żyć; wszystko zaczyna mieć sens, wiesz o czym jest, gdzie to zmierza, co robią i mówią stworzone postacie; zaczynasz się czuć twórcą i odbiorcą jednocześnie. Wszystko zaczyna być oczywiste i zaskakujące jednocześnie; magiczne, cudowne i dziwne ${ }^{5}$ (Gaiman 2007).

Oczywiście jest to opis bardzo subiektywny, spisany piórem profesjonalnego pisarza, jednakże pokazuje, jak proces tworzenia tekstów (powieści, historii) kojarzony jest z procesem wyjątkowym, na swój sposób katartycznym. Mimo że Gaiman odnosi się do własnych doświadczeń (a jest znanym pisarzem, autorem wielu książek, komiksów), to nie można odmówić doświadczania zbliżonych emocji młodym pisarzom dopełniającym twórczego aktu - także tego wspieranego przez grę.

Myśl freinetowska, kładąca duży nacisk na samodzielne konstruowanie wypowiedzi pisemnych przez wychowanków, wydaje się bliskim teoretycznie gruntem dla rozważania potencjału gier takich jak Elegy for the Dead World. Oczywiście

\footnotetext{
${ }^{5}$ Tłum. P.K. i P.P.
} 
przy uwzględnieniu specyficznego kontekstu, jakim jest cyfrowe środowisko świata przedstawionego. Powiązanie z indywidualnym doświadczeniem ucznia przyjmuje tu specyficzną formę immersyjnego zanurzenia w wirtualnym świecie gry (Filiciak 2006). Freinet, zwracający uwagę na praktyczne zastosowania zdolności czytania i pisania, odnosił się nie tylko do instrumentalnej funkcji tychże w kontakcie z materialną rzeczywistością, ale również do funkcji ludycznej (Legrand 1993). W przypadku gier wideo czytanie należałoby rozumieć szerzej - nie tylko w sensie literackim, lecz także jako odczytywanie innych elementów tego konkretnego medium: warstwy graficznej, dźwiękowej czy symbolicznych odniesień do innych elementów i dzieł kultury.

Także uzupełnianie lub tworzenie tekstu na podstawie danych ma tu specyficzne znaczenie. Sam Freinet w nauce pisania zwracał uwagę na istotny element, jakim jest komunikowanie poprzez tekst, rozumiany nie tylko jako pisanie - akt odizolowany od innych praktyk społecznych, lecz także nakierowany na dzielenie się wytworzonymi informacjami z innymi (Legrand 1993). O ile w jego, oraz jego kontynuatorów, przypadku przybierało to formę tworzenia gazetek, pracy uczniów przy fizycznie istniejącej prasie drukarskiej, o tyle udostępnianie efektów swego wysiłku pisarskiego poprzez sieć może stanowić doskonały odpowiednik tej praktyki, na miarę możliwości XXI stulecia.

\section{Potencjał gier wideo}

Gry wideo - nawet, gdy niezaklasyfikowane do gatunki gier edukacyjnych - posiadają potencjał uczący oraz kulturotwórczy. Są „wariacją codzienności”, propozycją rozumienia znaczeń, a więc namawiają do dyskutowania; zachęcają do obserwacji, konstruowania (także technicznego jak w Cargo! The Quest for Gravity studia Ice-Pick Lodge), zatapiania się w szczegółach - jak również w Elegy for a Dead Worldodczytywania obrazów, znaczeń, nastrojów. Zachęcają do odpowiedzi, kreowania, niekiedy niszczenia. Owszem, nie są idealne, ale stanowią możliwość.

Niewątpliwym minusem Elegy for a Dead World na rynku polskim jest brak polskiej wersji językowej ${ }^{6}$, jednakże czy nie można zaproponować tej gry dzieciom, które poznają język, i w ten sposób połączyć treści artystyczne, edukacyjne oraz językowe?

Gry wideo są częścią kultury popularnej - kultury bombardującej, pełnej bodźców, wszechobecnej, bliskiej uczniom XXI wieku (Melosik 2015). Czasami warto przypomnieć o tym pedagogom, nauczycielom, wychowawcom i edukować ich o potencjale gier wideo. Pewne jest, że szkoła nie powinna tabuizować gier wideo, nadawać im cech "głupoty”, nieakceptowalnej infantylności, antytezy nauki. Czyniąc tak, poddaje się w wątpliwość także inne teksty kultury - np. kinematografię, literaturę. Gry wideo zmieniały się przez lata; stawały się bardziej rozbudowane,

\footnotetext{
${ }^{6}$ Stan na 28.02.2017.
} 
dotykające większej ilości tematów; obecnie oferują wiele różnych form doświadczania i poznawania. To fakt, którego pedagodzy powinni być świadomi.

Warto w tym miejscu wspomnieć, że gry wideo, jako element rzeczywistości kulturowej, w której funkcjonujemy, posiadają pewne unikalne właściwości predysponujące je do wspomagania procesów edukacyjnych. Jak wynika z prowadzonych na ten temat badań psychologicznych, granie może przynosić konkretne efekty w zakresie rozwijania mechanizmów poznawczych (Bavelier 2012). Dodatkowo wspomniany wcześniej mechanizm immersji (Filiciak 2006) czyni doświadczenia czerpane z rozgrywki bliższymi niż te, które mogą być przekazywane przez inne, bardziej tradycyjne media. Kolejnym istotnym czynnikiem w tym zakresie jest rozwijanie postawy twórczej poprzez zjawiska i formy działań związane bezpośrednio z grami. Najbardziej chyba oczywistym przykładem takiej praktyki społecznej jest kreacja tak zwanych modów, czyli nieoficjalnych dodatków do gier tworzonych przez samych użytkowników.

Tworzenie modów (ang. modding) stanowi bardzo specyficzną formę działalności oddolnej, mającej swe źródło w dobrowolnej pracy zaangażowanych użytkowników konkretnej aplikacji. Z reguły jest działalnością nieodpłatną. W swej naturze wydaje się mieć charakter kompensacyjny, tzn. gracze koncentrują zwykle swe wysiłki w celu poprawy tych elementów rozgrywki, które w ich opinii są wybrakowane, niedoskonałe lub mogłyby zostać bardziej rozbudowane (Prósinowski, Krzywdziński 2016). Szczególnie istotny jest tu fakt, że wraz z tworzeniem tego typu dodatków nierozerwalnie łączy się ich upublicznianie i udostępnianie szerokiemu gronu odbiorców. Upodabnia to tym samym działalność moderską do freinetowskiej idei społecznego komunikowania się za pomocą tworzonego tekstu jako istotnego elementu procesu kształcenia.

\section{Myśli końcowe. O pedagogice, game studies i dalszych wyzwaniach}

Gry wideo mogą być naznaczone ideami bliskimi pedagogice. Posiadają potencjał inkulturacyjny, edukacyjny, niekiedy wychowawczy. Mogą skłaniać do refleksji, lecz mogą także tematy spłycać. To dlatego potrzebni są badacze z dziedziny game studies - także wśród pedagogów, bo komu bliższe są wychowanie, edukacja, inspirowanie, działanie z dziećmi, młodzieżą, czasami też dorosłymi?

Istnieją gry, takie jak Elegy for a Dead World, mogące działać na wiele sposobów, oferować zabawę, która także uczy. Są gry wymagające czytania, podejmowania decyzji oraz analizy (jak gry typu cRPG, np. Planescape: Torment ${ }^{7}$ ). Są także gry

${ }^{7}$ Planescape Torment zaklasyfikowane jest jako gra dla dojrzalszych graczy w wieku około 16+. Duża część cRPG skierowana jest dla starszych ze względu na trudniejsze treści, swoje skomplikowanie, bardziej dosadne obrazowanie zdarzeń, niekiedy nieodpowiednie dla młodych, początkujących odbiorców. Jednocześnie jednak stają się ciekawym materiałem do analizy w kontekście starszych graczy; dostarczają kontekstu do dyskusji kwestii bardziej kompleksowych. 
przypominające baśnie, oferujące ciekawe postacie, kreacje, rozwiązania graficzne (np. Ori and the Blind Forest czy Seasons after Fall).

W praktyce pedagogicznej (także psychologicznej, socjologicznej czy kulturoznawczej) nierzadko możemy być pytani przez rodziców, opiekunów, edukatorów, studentów o gry wideo, ich możliwy wpływ, zagrożenia z nimi związane. Warto więc pamiętać, że poza często wspominanymi zagrożeniami ze strony gier (treści nieodpowiednie dla uczniów/dzieci w konkretnym wieku, dyskryminacja wewnątrz fabuły gry, stereotypowe przedstawienie postaci/zjawiska, zbyt duże ilości czasu spędzane przed komputerem/tabletem/konsolą) oraz zagrożeń w czasach technologii cyfrowych w ogóle (Prymak 2014), gry posiadają także potencjał i mogą pomóc tam, gdzie szkoła zawodzi (możliwość ekspresji, wypoczynku, nauki/treningu języków, poznania tematów na co dzień tabuizowanych, poznania ludzi spoza najbliższego grona - ludzi z innych kontynentów, a udzielających się na tym samym portalu co uczeń/dziecko), a czasy rozwoju cyfrowego posiadają także inne oblicze - oblicze perspektyw i dokonań do niedawna jeszcze niemożliwych właśnie z powodu ograniczeń technologicznych.

\section{Literatura}

Bavelier D., 2012, Gry wideo a mózg, http://www.ted.com/talks/daphne_bavelier_your_ brain_on_video_games?language $=$ pl\#t-1053457 [dostęp: 7.03.2015].

Braun-Gałkowska M., Ulfik-Jaworska I., 2002, Zabawa w zabijanie, Lublin: Wydawnictwo Archidiecezji Lubelskiej „Gaudium”.

Dejobaan Games, 2014, http://www.dejobaan.com/elegy/ [dostęp: 30.11.2015].

Dennis J.P., 2010, Drawing Desire: Male Youth and Homoerotic Fan Art, „Journal of LGBT Youth" Vol. 7, Iss. 1.

Filiciak M., 2006, Wirtualny plac zabaw. Gry sieciowe i przemiany kultury współczesnej, Warszawa: Wydawnictwa Akademickie i Profesjonalne.

Freinet C., 1976, O szkołe ludowa: pisma wybrane, red. A. Lewin, H. Semenowicz, tłum. H. Semenowicz, Wrocław: Zakład Narodowy Imienia Ossolińskich.

Gaiman N., 2007, Why write?, http://journal.neilgaiman.com/2007/10/why-write.html [dostęp: 30.11.2015].

Game Industry Trends, 2014, www.git2013.pl/konto/materialy [dostęp: 30.11.2015].

Huizinga J., 1985, Homo Ludens. Zabawa jako źródło kultury, tłum. M. Kurecka, W. Wirpsza, Warszawa: Czytelnik.

Jestem graczem, 2013, http://www.jestemgraczem.com/ [dostęp: 30.11.2015].

Legrand L., 1993, Celestin Freinet, „Prospects: The Quarterly Review Of Comparative Education” Vol. 23, No. 1/2, http://www.ibe.unesco.org/sites/default/files/freinete.pdf [dostęp: 20.02.2017].

Margarita A., Montenegro L., 1994, The „Global Method” of Celestin Freinet: Whole language in European setting?, „The Reading Teacher" Vol. 48, No. 1.

Melosik Z., 2012, Mass media, tożsamość i rekonstrukcje kultury współczesnej [w:] Media - Edukacja - Kultura, red. W. Skrzydlewski, S. Dylak, Poznań-Rzeszów: Polskie Towarzystwo Technologii i Mediów Edukacyjnych. 
Melosik Z., 2015, Nauczyciele i kultura popularna: konteksty działań pedagogicznych [w:] Nauczyciel w ponowoczesnym świecie, red. J. Pyżalski, Łódź: the Q Studio.

Miller R., 1977, Wychowanie przez świat fikcyjny dla świata rzeczywistego we wczesnym dzieciństwie [w:] Sztuka dla najmłodszych, red. M. Tyszkowa, Warszawa: Państwowe Wydawnictwo Naukowe.

Ming Cheung W., Kam Tse S., Wh Tsang H., 2003, Teaching Creative Writing Skills to Primary School Children in Hong Kong: Discordance Between the Views and Practices of Language Teachers, „The Journal of Creative Behavior” Vol. 37, Iss. 2.

Nikolajeva M., 2014, Reading for Learning: Cognitive approaches to children's literature, Amsterdam: John Benjamins Publishing.

Paleczny T., 2012, Transgresyjne formy zabawy w świecie ponowoczesnym [w:] Kultura zabawy, red. T. Paleczny, R. Kantor, M. Banaszkiewicz, Kraków: Wydawnictwo Uniwersytetu Jagiellońskiego.

Prósinowski P., Ranachowska J., 2014, Męskość na waszych ekranach: konstrukty mężczyzn i ich seksualności $w$ komputerowych grach fabularnych, filmach i reklamach, „Ars Educandi" t. 11, red. H. Bougsiaa, L. Kopciewicz, M. Welenc.

Prósinowski P., 2015, To, co męskie, to, co kobiece. Konstrukty płci i seksualności w grach komputerowych [w:] Codzienność, performatywność, edukacja, red. L. Kopciewicz, B. Simlat-Żuk, Gdańsk: Wydawnictwo Katedra.

Prósinowski P., Krzywdziński P., 2016, Gry wideo a postawa twórcza: potencjał i narracja zagrożeń, „Ars Educandi” t. 12: Światy wyobrażone a codzienność, red. P. Prósinowski, P. Krzywdziński.

Prymak T., 2014, O patologii i zagrożeniach cyfrowego pokolenia, „Problemy Wczesnej Edukacji” nr 4 (27).

Rodziewicz E., 2011, Między wstępem a tekstem. Co robi fikcja w pedagogice Romany Miller $i$ w naszej książce [w:] Wychowanie przez świat fikcyjny dla świata rzeczywistego, red. E Rodziewicz, M. Cackowska, Gdańsk: Wydawnictwo Uniwersytetu Gdańskiego.

Stawinoga R., 2007, Twórczość językowa dziecka w teorii i praktyce edukacyjnej, Lublin: Wydawnictwo Uniwersytetu Marii Curie-Skłodowskiej.

Szeja J.Z., 2004, Gry fabularne - nowe zjawisko kultury współczesnej, Kraków: Rabid.

Wierzba P., 2015, Edukacja w czasach popkultury. Pedagogika kultury popularnej we wspótczesnej praktyce edukacyjnej, „Teraźniejszość - Człowiek - Edukacja” t. 18, nr 2(70).

\section{Ludografia}

Black Isle Studios, 1999, Planescape: Torment, Interplay Entertainment.

Dejobaan Games, 2014, Elegy for a Dead World, 2014, Popcannibal Games.

Ice-Pick Lodge, 2011, Cargo! Quest for Gravity.

Moon Game Studios, 2015, Ori and the Blind Forest, Microsoft Studios.

Swing Swing Submarine, 2016, Seasons after Fall. 


\begin{abstract}
Abstrakt
Poznawanie, nazywanie, odczytywanie i nadawanie znaczeń to jedne z najistotniejszych aktywności dziecka. Dziecięce poznawanie świata, eksperymentowanie stają się kluczem do życia społecznego oraz rozwoju jednostki. Poznawanie świata prowadzi także do inkulturacji, dostrzegania złożoności rzeczywistości, umiejętności dostrzegania i analizy tego, co nas otacza. Początkowo doświadczanie jest proste, niekiedy powierzchniowe, lecz wraz z rozwojem dziecko jest w stanie dokonywać nowych eksperymentów poznawczych oraz uczyć się. Oczywiste jest, że istnieje wiele sposobów wspierania rozwoju - współdziałanie z innymi, działania artystyczne, zabawa etc. Wspierać potrafią także różne teksty kultury: animacje, muzyka, literatura dziecięca i młodzieżowa. Jednak rzadko wspomina się o grach wideo w kontekście wspierania dziecięcego poznawania świata. Celem tekstu jest ukazanie możliwego wsparcia rozwoju dziecka ze strony gier wideo - za przykład posłuży gra Elegy for a Dead World (której rozgrywka posiada wiele wspólnych cech z metodą swobodnego tekstu Celestyna Freineta) studia Dejobaan Games, jak i inne teksty kultury.
\end{abstract}

\title{
Słowa kluczowe
}

dziecko, gry wideo, game studies, edukacja, nowe media, ludologia

\section{Summary}

The potential of video games: giving meanings to phenomena, inculturation and literary development of young gamers

Discovering, naming, reading and giving meaning to objects/phenomena is one of the most significant activities a child may engage in. Child's way of discovering the world, experimenting, are a key to socialisation and mental development. Learning about the world also helps in realizing how complex reality is; it aids in development of seeing and ability to analyse our cultural environment. In the beginning, the patter of discovery is simple, but along with child's development, it becomes able to perform more advanced experiments. It begins to learn differently. It is obvious, that there are many ways of supporting the development - performing acts with different children/human being; engaging in artistic processes; playing etc. There are many different types of text of culture that may support children in their development: different animations, music, literature. Rarely video games are mentioned as a possible support of child's development. The aim of this text is to present how video games can aid children, teach them, educate. In the specific text will focus on a game Elegy for a Dead World (which has features similar to Freinet's free text method) by Dejobaan Games, and some other examples of video games.

\section{Keywords}

child, video games, game studies, education, new media, ludology 